\title{
Pengaruh Perencanaan dan Penganggaran terhadap Kinerja Perangkat Daerah pada Badan Perencanaan Pembangunan Daerah Kabupaten Kutai Timur
}

\author{
Yulia Ariesmawati ${ }^{\text {a* }}$ \\ ${ }^{a}$ Bappeda Kabupaten Kutai Timur, Kalimantan Timur, Indonesia
}

INFORMASI ARTIKEL

Article history:

Dikirim tanggal: 18 September 2019

Revisi pertama tanggal: 08 Juli 2020

Diterima tanggal: 30 Juli 2020

Tersedia online tanggal: 25 Agustus 2020

Keywords: planning, budgeting, performance, East Kutai Regency

\begin{abstract}
The purpose of the study is to determine planning and budgeting impact partially on as performance indicator of the regional organization in Regional Development Planning Departement of East Kutai Regency in East Kalimantan Province. This research using quantitative approach, with responden survey method, which was conducted on 58 State Civil Apparatuses (ASN) with qualification minimum hold bachelor degree as responden. Data analysis using descriptive and inferential statistics. The results describe that there ware positive and significant correlation between planning and budgeting impact in partially with performance of regional organization in Regional Development Planning Department (Bappeda) East Kutai Timur.
\end{abstract}

\section{INTISARI}

Tujuan dari penelitian ini adalah untuk mengetahui pengaruh perencanaan dan penganggaran secara parsial terhadap kinerja Perangkat Daerah pada Badan Perencanaan Pembangunan Daerah Kabupaten Kutai Timur, Provinsi Kalimantan Timur. Penelitian ini menggunakan pendekatan kuantitatif, metode yang digunakan adalah metode survei, yang dilakukan pada 58 Aparatur Sipil Negara (ASN) yang berpendidikan minimal S1. Data dianalisis dengan statistik deskriptif dan inferensial. Hasil penelitian menunjukkan bahwa terdapat pengaruh yang positif dan signifikan antara perencanaan dan penganggaran secara parsial terhadap kinerja perangkat daerah Badan Perencanaan Pembangunan Daerah (Bappeda) Kabupaten Kutai Timur.

\section{Pendahuluan}

Perubahan sistem pemerintahan dan pengelolaan pembangunan daerah pada era otonomi daerah dan desentralisasi tentunya akan menimbulkan perubahan yang mendasar dalam perencanaan pembangunan daerah, dibandingkan dengan era sentralisasi orde baru. Perubahan dasar yang terjadi pada era otonomi menyangkut dua hal pokok, yaitu dalam hal desentralisasi pembangunan dan desentralisasi fiskal (Sjafrizal, 2017, p. 14). Dengan beralihnya sebagian besar proses pengambilan keputusan dalam perencanaan, pelaksanaan dan evaluasi penyelenggaraan pemerintahan dari pusat ke daerah, pemerintah daerah bertanggung jawab secara penuh terhadap kebijakan-kebijakan dasar yang diperlukan bagi pembangunan daerah (Sun'an \& Senuk, 2015, p. 3).

Perencanaan pembangunan pada dasarnya adalah cara atau teknik untuk mencapai tujuan pembangunan

* Corresponding author. Tel.: +62-852-5089-4968; e-mail: yulia_ariesmawati@yahoo.co.id 
secara tepat, terarah dan efisien sesuai dengan kondisi negara atau daerah (Sjafrizal, 2017, p. 24).

Penganggaran merupakan proses atau metode untuk mempersiapkan suatu anggaran. Tahap penganggaran sangat penting karena anggaran yang tidak efektif dan tidak berorientasi pada kinerja akan menggagalkan perencanaan yang sudah disusun (Mardiasmo, 2002b, p. 61).

Dalam perencanaan anggaran sektor publik, di era reformasi ditandai dengan lahirnya era New Public Management (NPM), hal ini merupakan usaha untuk mendorong pengembangkan perencanaan dengan pendekatan yang sistematis (Mardiasmo, 2002a, p. 83).

Salah satu aspek utama reformasi anggaran (budgeting reform) adalah perubahan dari traditional budget ke performance budget (Hanafi \& Mugroho, 2009, p. 49).

Anggaran berbasis kinerja suatu pendekatan penganggaran yang merupakan penggunaan anggaran dengan kualitas dan kuantitas terukur yang mengutamakan keluaran/ hasil dari suatu program/ kegiatan (Suhadak \& Nugroho, 2007, p. 21).

Anggaran kinerja adalah sebuah sistem anggaran yang mengutamakan pencapaian output dari input yang ditetapkan. Anggaran kinerja didasarkan pada tujuan dan sasaran kinerja. Penerapan sistem anggaran kinerja dimulai dengan perumusan program serta penentuan indikator kinerja yang digunakan sebagai tolak ukur dalam mencapai tujuan program yang telah ditetapkan (Mardiasmo, 2002b, p. 84).

Dalam anggaran berbasis kinerja, untuk melaksanakan program/ kegiatan, harus terukur jelas indikator kinerjanya, yang direpresentasikan kedalam tolak ukur kinerja serta target/ sasaran yang diharapkan, sehingga akan ada keterkaitan antara dana yang tersedia dengan hasil yang diharapkan, hal ini dapat dilakukan dengan cara membangun sistem penganggaran yang memadukan antara perencanaan kinerja dan anggaran (Suhadak \& Nugroho, 2007, p. 21).

Untuk menilai keberhasilan atau kegagalan pelaksanaan kebijakan/ program/ kegiatan yang sesuai dengan sasaran dan tugas yang telah ditetapkan, dalam rangka mewujudkan visi dan misi pemerintah daerah, maka diperlukan suatu pengukuran kinerja (Suhadak \& Nugroho, 2007, p. 22).

Namun banyak hal yang dapat menyebabkan tidak terlaksananya konsistensi perencanaan dan penganggaran (Sjafrizal, 2017, p. 134), antara lain sebagai berikut:

a) Penyusunan RKPD sejak awal sudah tidak konsisten dengan penyusunan rancangan APBD;

b) Terbatasnya anggaran yang tersedia sehingga program dan kegiatan yang di RKPD tidak dapat di dukung anggaran; dan c) Adanya kekuatan tertentu baik di eksekutif maupun legislatif yang mengubah program kegiatan yang direncanakan.

Selain itu dalam prakteknya sering dijumpai adanya perencanaan jangka panjang yang tidak terkait dengan perencanaan jangka pendek. Anggaran tahunan disusun tanpa berlandasakan pada program yang telah ditetapkan, sehingga proses pengukuran kinerja suatu organisasi menjadi tidak terarah dan tidak fokus. Hal ini dapat mengakibatkan kinerja organisasi yang dihasilkan bukan kinerja organisasi sesungguhnya, sehingga disebut menjadi bersifat semu (artificial performance) (Mahsun dkk., 2016, p. 156).

Untuk mengatasi permasalahan-permasalahan tersebut diatas, dengan menggunakan Teori New Public Management (NPM) sebagai pendekatan dalam anggaran berbasis kinerja yang berfokus pada manajemen kinerja sektor publik, dengan menggunakan konsep anggaran berbasis kinerja sebagai tanggungjawab untuk merumuskan program yang konsisten dengan tujuan pembangunan, selain itu juga mengacu pada dasar regulasi yang digunakan Undang-Undang Nomor 25 Tahun 2004, Undang-Undang Nomor 23 Tahun 2014, Peraturan Pemerintah Nomor 8 Tahun 2008, dan Peraturan Pemerintah Nomor 12 Tahun 2019 serta Peraturan Menteri Dalam Negeri Nomor 86 Tahun 2017, serta merujuk penelitain terdahulu sebagai referensi tentang pentingnya perencanaan dan penganggaran sebagai konsep utama dalam pembangunan daerah. Oleh karena itu perlu dilakukan penelitian tentang pengaruh perencanaan dan penganggaran terhadap kinerja Perangkat Daerah pada Badan Perencanaan Pembangunan Daerah (Bappeda) Kabupaten Kutai Timur Provinsi Kalimantan Timur.

Berdasarkan latar belakang yang telah diuraikan diatas, penelitian ini dilakukan dengan tujuan untuk mengetahui pengaruh perencanaan dan penganggaran secara parsial terhadap kinerja Perangkat Daerah pada Bappeda Kabupaten Kutai Timur Provinsi Kalimantan Timur.

\section{Teori}

\subsection{Perencanaan Pembangunan Daerah}

Teori pembangunan adalah teori yang berhubungan dengan masalah-masalah pembangunan, yang berhubungan dengan pertumbuhan dan perubahan yang terencana yang terjadi di suatu masyarakat atau suatu daerah atau suatu negara guna meningkatkan kesejahteraan manusia (Hardjanto, 2011, p. 1).

Ruang lingkup perencanaan pembangunan nasional terdiri atas perencanaan pembangunan yang disusun secara terpadu oleh kementerian/ lembaga dan daerah 
sesuai dengan kewenangannya. Perencanaan yang akan dihasilkan adalah sebagai berikut (Bastian, 2009, p. 17):

a) Rencana Pembangunan Jangka Panjang;

b) Rencana Pembangunan Jangka Menengah; dan

c) Rencana Pembangunan Tahunan.

Rencana pembangunan jangka panjang tertuang dalam dokumen Rencana Pembangunan Jangka Panjang (RPJP) yang merupakan dokumen perencanaan untuk periode 20 tahun, sedangkan rencana pembangunan jangka menengah, untuk periode lima tahun, tertuang dalam dokumen Rencana Pembangunan Jangka Menengah (RPJM) dan Rencana Strategis (Renstra) Perangkat Daerah, sedangkan untuk rencana pembangunan satu tahun atau tahunan tertuang dalam dokumen Rencana Kerja Pemerintah (RKP) yang merupakan dokumen perencanaan nasional dan Rencana Kerja Pemerintah Daerah (RKPD) untuk dokumen perencanaan daerah serta Rencana Kerja (Renja) Perangkat Daerah untuk dokumen perencanaan daerah dengan periode satu tahun.

Penganggaran menurut Elmi (2002) dalam Khusaini (2006, p. 180) adalah suatu proses menyusun rencana keuangan, pendapatan, dan pembiayaan, yang kemudian dialokasikan dana tersebut sesuai dengan fungsi dan sasaran yang hendak dicapai. Sedangkan untuk rencana kerja pemerintah daerah tahunan (satu tahun) dalam bentuk uang disebut anggaran daerah.

Dokumen penganggaran tahunan daerah, antara lain:

a) Kebijakan Umum APBD;

b) Prioritas dan Plafon Anggaran Sementara (PPAS);

c) Rencana Kerja dan Anggaran (RKA) SKPD; dan

d) Anggaran Pendapatan dan Belanja Daerah (APBD).

Untuk dapat mewujudkan tujuan pembangunan sesuai dengan Undang-Undang Nomor 25 Tahun 2004, maka perlu dijamin antara keterkaitan dan konsistensi antara perencanaan, penganggaran, pelaksanaan, dan pengawasan.

Keterkaitan antara perencanaan dan penganggaran perlu terus diupayakan, karena pelaksanaan pembangunan yang telah direncanakan hanya dapat dilakukan dengan baik, bila anggaran tersedia untuk program dan kegiatan (Sjafrizal, 2017, p. 29).

Menurut Caiden \& Wildavsky (1974, p. 275) konsisten (consistent) merupakan salah satu ciri dari perencanaan yang baik. Sebagai tindakan yang rasional, perencanaan yang baik mempunyai ciri-ciri antara lain sistematis, efisien, terkoordinasi, konsisten, dan rasional.

\subsection{New Public Management (NPM)}

Munculnya konsep New Public Management (NPM), yang merupakan salah satu gerakan reformasi publik, yang awalnya diperkenalkan oleh Christopher Hood pada Tahun 1991. Dari perspektif historis, pada 1980-an dan 1990-an di Eropa, muncul pendekatan manajemen modern disektor publik, hal ini sebagai reaksi terhadap tidak memadai administrasi tradisional (Mahmudi, 2015, p. 36).

Model pemerintahan menurut Osborne \& Gaebler (1992) di Era New Public Management (NPM) (Mardiasmo, 2002a, p. 79), yaitu pemerintah yang digerakkan oleh misi, mengubah organisasi yang digerakkan oleh peraturan menjadi organisasi yang lebih banyak digerakkan oleh tujuan yang menjadi misinya.

Menurut Hood (1991) dalam Mindarti (2016, p. 140), Konsep New Public Management (NPM) memiliki ciri utama yang lebih mendasarkan pada prinsip, antara lain sebagai berikut:

a) Penggunaan indikator kinerja;

b) Penekanan yang lebih besar pada kontrol output; dan

c) Pergeseran ke kompetisi yang lebih tinggi dalam pelayanan publik.

Implementasi NPM pada reformasi organisasi publik saat ini adalah perbaikan pengelolaan sumber daya secara efisien dan efektif, dengan memperhatikan aspek value for money, yaitu: ekonomi, efisien dan efektif, sehingga mencapai kinerja organisasi secara optimal (Halim \& Kusufi, 2014, p. 15).

Tuntutan pembaharuan (reformasi) sistem keuangan pada organisasi publik memiliki tujuan agar pengelolaan uang publik dapat dilakukan secara transparan berdasarkan konsep value for money, sehingga dapat menciptakan akuntabilitas publik (Halim \& Kusufi, 2014, p. 16).

\subsection{Anggaran Berbasis Kinerja}

Anggaran berbasis kinerja adalah pendekatan penganggaran yang mengukur kualitas dan kuantitas keluaran/ hasil dari program/ kegiatan yang akan atau telah dicapai (Suhadak \& Nugroho, 2007, p. 21).

Pada Tahun 1949 di Amerika Serikat pertama kali diperkenalkan performance budgeting, tetapi mengalami kegagalan, sehingga pada reformasi anggaran Tahun 1990-an, karaktristik yang penting dan bermanfaat dalam kontek administrasi publik dikembangkan secara bersama (Bastian, 2010, p. 202).

Pengenalan penganggaran kinerja memberikan kesempatan untuk meningkatkan kualitas perencanaan, dan mengembangkan rencana anggaran yang menghubungkan tujuan perencanaan strategis dengan proses sumber daya dalam jangka menengah (OECD 2018, p. 16).

Anggaran yang berorientasi kinerja (performance budgeting) merupakan sistem penganggaran yang berorientasi pada pengukuran output (output measurement) organisasi, dengan alokasi sumber daya ke program bukan pada unit organisasi, yang berhubungan dengan visi, misi, serta rencana strategi organisasi, dengan mempertimbangkan biaya unit (unit cost) dan beban kerja (work load) dari setiap kegiatan. Tujuan dari penetapan pengukuran kinerja output (output 
measurenment) yang dikaitkan dengan biaya adalah mengukur tingkat efisiensi dan efektivitas. Hal ini merupakan alat untuk dapat menjalankan prinsip akuntabilitas, karena merupakan output dari suatu proses kegiatan organisasi (Bastian, 2010, p. 202).

Manfaat yang diperoleh dengan menggunakan anggaran berbasis kinerja, menurut Suhadak \& Nugroho (2007, p. 109) antara lain sebagai berikut:

Target tingkat pencapaian output dan outcome dapat diketahui;

a) Output dan outcome yang dihasilkan dari setiap program dapat teridentifikasi;

b) Berhubungan dengan biaya (input) yang digunakan dengan hasil yang diinginkan dan proses perencanaan strategis yang sebelumnya dilakukan;

c) Setiap jenis pengeluaran yang dilakukan oleh dinas dapat diketahuinya urutan prioritas; dan

d) Sebagai media pertanggungjawaban setiap satuan kerja atas hasil yang dicapainya.

Konsep tentang anggaran berbasis kinerja menurut Suhadak \& Nugroho (2007, p. 21) bahwa dalam anggaran berbasis kinerja yaitu dengan sistem penganggaran yang memadukan antara perencanaan kinerja dan penganggaran, oleh karena itu program/ kegiatan harus terukur jelas indikator kinerja serta target/ sasaran.

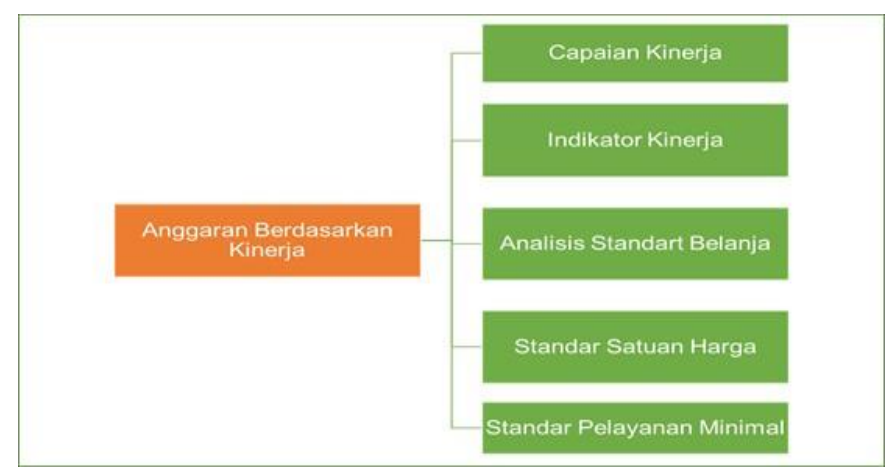

Gambar 1 Anggaran Berdasarkan Kinerja

Sumber: Suhadak \& Nugroho (2007, p. 23)

\subsection{Pengukuran Kinerja}

Pengukuran kinerja (performance measurement) menurut Robertson (2002) dalam Mahsun dkk (2016, p. 141) merupakan proses penilaian kemajuan pekerjaan terhadap tujuan dan sasaran yang telah ditetapkan, termasuk tentang efisiensi, hasil kegiatan dibandingkan dengan target dan efektivitas dalam mencapai tujuan.

Untuk menilai keberhasilan atau kegagalan pelaksanaan kebijakan/ program/ kegiatan yang sesuai dengan sasaran dan tugas yang telah ditetapkan, dalam rangka mewujudkan visi dan misi pemerintah daerah, maka diperlukan suatu pengukuran kinerja (Suhadak \& Nugroho, 2007, p. 22).

Pemahaman tentang perencanaan (planning and budgeting) ditinjau dari fungsi manajemen merupakan suatu keterkaitan yang tidak dapat dipisahkan antara penganggaran (budgeting) dengan perencanaan (planning), hal ini sangat diperlukan dalam penyusunan anggaran (Suhadak \& Nugroho, 2007, p. 49).

\subsubsection{Perencanaan Kinerja}

Dalam proses manajemen perencanaan merupakan fungsi awal dalam menentukan arah untuk mencapai tujuan, sehingga definisi dari perencanaan adalah proses pemikiran dan penentuan yang akan dikerjakan dalam mencapai tujuan yang ditentukan (Suhadak \& Nugroho, 2007, p. 49).

Menurut Mahsun (2014, p. 37), pada organisasi sektor publik, proses pengendalian manajemen yang mencakup aktivitas formal, antara lain sebagai berikut:

a) Perumusan strategi, merupakan tugas dan tanggung jawab manajemen puncak, yang meliputi proses penentuan visi, misi, tujuan, sasaran, target dan kebijakan serta strategi organisasi;

b) Perencanaan strategi, proses organisasi dalam menentukan program, kegiatan (proyek/ aktivitas), sehingga menghasilkan rencana strategis (strategic planning);

c) Penganggaran, tahap ini dalam proses pengendalian sektor publik yang dominan;

d) Pelaksanaan anggaran; dan

e) Evaluasi kinerja.

\subsubsection{Penganggaran Kinerja}

Proses penganggaran pada sektor publik berbeda dengan proses penganggaran sektor swasta, hal ini karena adanya proses politik dalam penganggaran publik. (Mahsun dkk., 2016, p. 155).

Penganggaran menurut regulasi diatur dalam pasal 93-95 Peraturan Pemerintah Nomor 12 Tahun 2019 tentang Pengelolaan Keuangan Daerah; bahwa dalam menyusun Rencana Kerja dan Anggaran (RKA) Satuan Kerja Perangkat Daerah (SKPD) berdasarakan KUAPPAS dengan pendekatan penganggaran berdasarkan kinerja dengan memadukan seluruh proses perencanaan dan penganggaran di lingkungan SKPD.

Menurut Suhadak \& Nugroho (2007, p. 111) untuk menilai dalam pelaksanaan sistem anggaran kinerja terdapat beberapa tolak ukur, yaitu antara lain sebagai berikut:

a) Indikator Kinerja;

b) Analisis Standar Biaya (ASB);

c) Standar Satuan Harga; dan

d) Standar Pelayanan Minimal (SPM).

\subsubsection{Kinerja Organisasi}

Pengukuran kinerja merupakan bagian dari fungsi manajemen kinerja yang merupakan dasar untuk melakukan penilaian kinerja yang digunakan untuk melakukan pengendalian aktivitas yang terukur 
kinerjanya agar dapat diketahui tingkat efisiensi dan efektivitasnya (Mahmudi, 2015, p. 81).

Informasi mengenai kinerja merupakan hal yang sangat penting dalam rangka meningkatkan kinerja sektor publik dan menciptakan good governance, maka diperlukan manajemen kinerja yang berorientasi pada Value For Money (VFM) (Mahmudi, 2015, p. 111).

Pengukuran kinerja Value for Money menurut Mahmudi (2015, p. 95) terdiri dari tiga komponen utama, yaitu sebagai berikut:

a) Komponen Visi, misi, tujuan, sasaran dan target;

b) Komponen input, proses, output dan outcome; dan

c) Komponen pengukuran ekonomi, efisiensi, dan efektivitas.

\subsection{Kerangka Konseptual}

Konsep dalam penelitian ini adalah anggaran berbasis kinerja, yang merupakan teknik penganggaran yang berorientasi pada kinerja, yang berfokus pada manajemen sektor publik dengan pendekatan New Public Management (NPM) (Hanafi \& Mugroho, 2009, p. 49).

Konsep anggaran berbasis kinerja, menurut Suhadak \& Nugroho (2007, p. 21), adalah

Indikator kinerja serta target/ sasaran program/ kegiatan harus terukur jelas, yaitu dengan cara membentuk sistem penganggaran yang memadukan antara perencanaan kinerja dan penganggaran.

Dalam penyusunan anggaran sangat diperlukan pemahaman tentang perencanaan (planning and budgeting) ditinjau dari fungsi manajemen merupakan suatu keterkaitan yang tidak dapat dipisahkan antara penganggaran (budgeting) dengan perencanaan (planning), hal ini sangat diperlukan dalam penyusunan anggaran (Suhadak \& Nugroho, 2007, p. 49).

Untuk konsep tentang perencanaan kinerja, menurut Mahsun (2014, p. 37), membagi sistem pengukuran kinerja menjadi lima tahapan, sedangkan untuk konsep perencanaan kinerja dibagi kedalam dua tahapan, yaitu perumusan strategi dan perencanaan strategi, yang kemudian dilanjutkan kedalam proses penganggaran. Sedangkan untuk konsep penganggaran, menurut Suhadak \& Nugroho (2007, p. 111), yang menilai sistem anggaran kinerja menjadi empat tolak ukur, yaitu: SPM, indikator kinerja, ASB, dan standar biaya.

Untuk konsep kinerja organisasi, menurut Mahmudi (2015, p. 97), untuk mengukur kinerja organisasi, dengan pengukuran value for money dengan komponen pengukuran ekonomi, efisien, dan efektivitas.

Konsep perencanaan dan penganggaran ini untuk mengukur kinerja dari organiasasi. Oleh karena itu peneliti merumuskan perencanaan dan penganggaran sebagai variabel independen (bebas), dan kinerja perangkat daerah merupakan variabel dependen (terikat).
Pada kerangka konseptual diatas, fokus pada penelitian yang akan dilakukan adalah perencanaan dan penganggaran terhadap kinerja perangkat daerah. Model penelitian yang akan dikembangkan adalah dengan mencari pengaruh perencanaan dan penganggaran sebagai variabel bebas (independent) dan kinerja perangkat daerah sebagai variabel terikat (dependent).

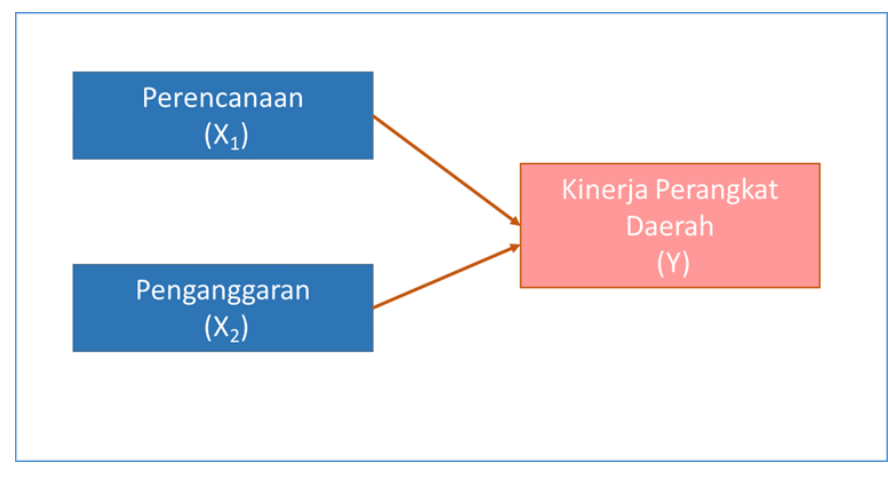

Gambar 2 Kerangka Konseptual

Sumber: Hasil analisis, 2019

Berdasarkan rumusan masalah, tinjauan pustaka dan kerangka konseptual, maka dirumuskan hipotesis penelitian sebagai berikut:

a. $\mathrm{Ha}_{1}$ : Ada pengaruh hubungan yang positif dan signifikan antara perencanaan dengan kinerja perangkat daerah.

b. $\mathrm{Ha}_{2}$ : Ada pengaruh hubungan yang positif dan signifikan antara penganggaran dengan kinerja perangkat daerah.

\section{Metode Penelitian}

\subsection{Metode}

Dalam penelitian ini menggunakan pendekatan kuantitatif, metode yang digunakan adalah metode survei. Penelitian kuantitatif berlandaskan pada filsafat positivisme, yang digunakan untuk meneliti populasi atau sampel tertentu, pengumpulan data menggunakan instrumen penelitian, dengan tujuan untuk menguji hipotesis yang telah ditetapkan (Sugiyono, 2017, p. 8).

Penelitian survey adalah penelitian yang mengambil sampel dari suatu populasi dan menggunakan kuesioner sebagai lat pengumpulan data pokok (Effendi \& Tukiran, 2017, p. 5). Untuk penelitian dengan tingkat eksplanasi atau penjelasan, yaitu yang menjelaskan hubungan kausal antar variabel melalui pengujian hipotesis (Effendi \& Tukiran, 2017, p. 5).

\subsection{Populasi dan Sampel}

Populasi dalam penelitian ini adalah Aparatur Sipil Negara (ASN) di lingkup Bappeda Kabupaten Kutai Timur, yang berjumlah 68 orang. Sedangkan pengambilan sampel yang akan digunakan oleh peneliti adalah purposive sampling. Purposive sampling 
merupakan pengambilan sampel dengan mengetahui terlebih dahulu sifat-sifat populasinya (Hakim 2016:107). Kriteria yang menjadi sampel adalah ASN yang berpendidikan minimal D4/ S-1.

\subsection{Pengukuran Variabel}

Pengujian instrumen penelitian dalam varaibel menggunakan uji validitas dan reliabilitas. Pengujian validitas dan reliabilitas instrumen penelitian memegang peranan penting dalam keseluruhan proses penelitian. Instrumen yang valid berarti alat ukur yang digunakan untuk memperoleh data juga valid (Hakim, 2016, p. 20).

Dengan menggunakan konsep anggaran berbasis kinerja menurut Suhadak \& Nugroho (2007, p. 21), dalam anggaran berbasis kinerja yang indikator kinerja serta target/ sasaran dalam melaksanakan program/ kegiatan harus terukur jelas, yaitu dengan cara membentuk sistem penganggaran yang memadukan antara perencanaan kinerja dan penganggaran.

\subsubsection{Variabel Independent}

Pada variabel independent (bebas) terdapat dua variabel, yaitu variabel perencanaan dan variabel penganggaran. Pada variabel perencanaan memiliki dua indikator, yaitu perumusan strategi dan perencanaan strategi. Sedangkan pada variabel penganggaran memiliki empat indikator, yaitu standar Pelayanan Minimal (SPM), indikator kinerja, Analisis Standart Belanja (ASB), dan standar satuan harga.

\subsubsection{Variabel Dependent}

Untuk variabel dependent (terikat) terdapat satu variabel, yaitu kinerja perangkat daerah, yang memiliki tiga indikator, yaitu ekonomis, efisiensi, dan efektifitas.

\section{Hasil Penelitian dan Pembahasan}

\subsection{Deskripsi Karakteritik Responden}

Responden dalam penelitian ini adalah Aparatur Sipil Negara (ASN) yang berpendidikan minimal D4/ S1 di lingkungan Badan Perencanaan Pembangunan Daerah (Bappeda) Kabupaten Kutai Timur. Total kuesioner yang dibagikan adalah 61 kuesioner, dan yang kembali dan dapat digunakan sebanyak 58 kuesioner $(95,1 \%)$.

Karakteristik responden berdasarkan jenis kelamin, usia, pendidikan, lama bekerja, dan keikutsertaan diklat dapat dilihat pada tabel 1 .

Tabel 1 Karakteristik Responden

\begin{tabular}{|l|l|c|c|}
\hline \multicolumn{2}{|c|}{ Karakteristik Responden } & Jumlah & $\begin{array}{c}\text { Persentase } \\
(\%)\end{array}$ \\
\hline \multirow{2}{*}{ Jenis Kelamin } & $\bullet$ Laki-Laki & 31 & 53 \\
\cline { 2 - 4 } & $\bullet$ Perempuan & 27 & 47 \\
\hline \multirow{4}{*}{ Usia (tahun) } & $\bullet<30$ & 2 & 3,4 \\
\cline { 2 - 4 } & $\bullet 30-35$ & 14 & 24,1 \\
\cline { 2 - 4 } & $\bullet 36-40$ & 19 & 32,8 \\
\cline { 2 - 4 } & $\bullet 41-45$ & 18 & 31 \\
\hline
\end{tabular}

\begin{tabular}{|l|l|c|c|}
\hline \multicolumn{2}{|c|}{ Karakteristik Responden } & Jumlah & $\begin{array}{c}\text { Persentase } \\
(\%)\end{array}$ \\
\hline \multirow{4}{*}{ Pendidikan } & $\bullet 46-50$ & 3 & 5,2 \\
\cline { 2 - 4 } & $\bullet>50$ & 2 & 3,4 \\
\hline \multirow{3}{*}{$\begin{array}{l}\text { Lama Bekerja } \\
\text { (tahun) }\end{array}$} & $\bullet$ D4/ S1 & 37 & 64 \\
\cline { 2 - 4 } & $\bullet$ S2 & 21 & 36 \\
\cline { 2 - 4 } & $\bullet$ S3 & 0 & 0 \\
\hline \multirow{3}{*}{$\begin{array}{l}\text { Keikutsertaan } \\
\text { diklat (kali) }\end{array}$} & $\bullet 2-5$ & 6 & 10 \\
\cline { 2 - 4 } & $\bullet>5$ & 32 & 35 \\
\cline { 2 - 4 } & $\bullet<3$ & 24 & 55 \\
\cline { 2 - 4 } & $\bullet>5$ & 0 & 0 \\
\hline
\end{tabular}

Sumber: Hasil analisis, 2019

\subsection{Analisis Uji Instrumen}

Dari pengumpulan data di lingkungan Badan Perencanaan Pembangunan Daerah (Bappeda) Kabupaten Kutai Timur, dengan 58 responden, maka untuk mengetahui valid dan reliabel atau tidak, maka dilakukan pengujian validitas dan reliabilitas instrumen.

Suatu instrumen dikatakan valid apabila adanya kesamaan antara data yang terkumpul dengan data yang sesungguhnya ada dan melekat pada obyek penelitian (Hakim, 2016, p. 19).

Pengujian validitas dalam penelitian ini, merupakan pengujian validitas tiap butir digunakan analisis item, yaitu mengkorelasikan skor tiap butir dengan skor total yang merupakan jumlah tiap butir (Sugiyono, 2017, p. 133). Pengujian corrected item total correlation, menggunakan program aplikasi Statistical Product and Service Solutions (SPSS).

Dasar pengambilan kevalidan adalah $r_{\text {hitung }}>r_{\text {tabel }}$, maka dapat dikatakan valid, jika $r_{\text {hitung }}<r_{\text {tabel }}$, maka dapat dikatakan tidak valid. Berdasarkan hasil pengolahan data, diperoleh hasil pengujian validitas seperti pada tabel 2 .

Tabel 2 Analisis Korelasi Setiap Item Instrumen dengan Skor Item

\begin{tabular}{|c|c|c|c|}
\hline \multirow{4}{*}{ Variabel } & $\begin{array}{l}\text { No.Butir } \\
\text { Instrumen }\end{array}$ & $\begin{array}{l}\text { Koefisien } \\
\text { Korelasi } \\
\left(\mathrm{r}_{\text {hitung }}\right.\end{array}$ & Keterangan \\
\hline \multirow{5}{*}{$\begin{array}{c}\text { Perencanaan } \\
\text { (X1) }\end{array}$} & 1 & 0,509 & Valid \\
\cline { 2 - 4 } & 2 & 0,733 & Valid \\
\cline { 2 - 4 } & 3 & 0,636 & Valid \\
\cline { 2 - 4 } & 4 & 0,694 & Valid \\
\cline { 2 - 4 } & 6 & 0,751 & Valid \\
\cline { 2 - 4 } & 7 & 0,807 & Valid \\
\cline { 2 - 4 } & 8 & 0,823 & Valid \\
\cline { 2 - 4 } & 9 & 0,685 & Valid \\
\cline { 2 - 4 } & 10 & 0,827 & Valid \\
\cline { 2 - 4 } & 1 & 0,676 & Valid \\
\cline { 2 - 4 } & 2 & 0,723 & Valid \\
\cline { 2 - 4 } & 3 & 0,626 & Valid \\
\cline { 2 - 4 } & 4 & 0,746 & Valid \\
\cline { 2 - 4 } & 5 & 0,735 & Valid \\
\cline { 2 - 4 } & 6 & 0,772 & Valid \\
\cline { 2 - 4 } & 7 & 0,675 & Valid \\
\hline
\end{tabular}




\begin{tabular}{|c|c|c|c|}
\hline \multirow{3}{*}{ Variabel } & $\begin{array}{l}\text { No.Butir } \\
\text { Instrumen }\end{array}$ & $\begin{array}{l}\text { Koefisien } \\
\text { Korelasi } \\
\left(\mathrm{r}_{\text {hitung }}\right)\end{array}$ & Keterangan \\
\hline \multirow{5}{*}{ Kinerja (Y) } & 8 & 0,429 & Valid \\
\cline { 2 - 4 } & 9 & 0,618 & Valid \\
\cline { 2 - 4 } & 10 & 0,579 & Valid \\
\hline & 1 & 0,720 & Valid \\
\cline { 2 - 4 } & 2 & 0,469 & Valid \\
\cline { 2 - 4 } & 3 & 0,607 & Valid \\
\cline { 2 - 4 } & 5 & 0,715 & Valid \\
\cline { 2 - 4 } & 6 & 0,840 & Valid \\
\cline { 2 - 4 } & 7 & 0,755 & Valid \\
\cline { 2 - 4 } & 8 & 0,741 & Valid \\
\hline
\end{tabular}

Sumber: Hasil analisis, 2019

Validitas variabel $\mathrm{X} 1 \quad$ (perencanaan), $\mathrm{X} 2$ (penganggaran) dan $\mathrm{Y}$ (Kinerja) dengan jumlah responden 58 orang dan dengan taraf signifikansi $5 \%$ maka berdasarkan tabel diperoleh $\mathrm{r}_{\text {tabel}}$, adalah 0,2588 , sehingga valid.

Untuk mengetahui suatu alat ukur reliabel atau tidak dalam penelitian ini diuji dengan menggunakan rumus coefisien alpha atau alpha cronbach $(\alpha)$. Hasil pengujian dengan alpha cronbach menggunakan program aplikasi Statistical Product and Service Solutions (SPSS). Berdasarkan hasil pengolahan data, diperoleh hasil pengujian reliabilitas seperti pada Tabel 3.

Tabel 3 Pengujian Reliabilitas Variabel

\begin{tabular}{|c|c|c|}
\hline Variabel & $\begin{array}{c}\text { alpha cronbach } \\
(\alpha)\end{array}$ & Keterangan \\
\hline Perencanaan (X1) & 0,926 & Reliabel \\
\hline Pengaggaran (X2) & 0,907 & Reliabel \\
\hline Kinerja (Y) & 0,900 & Reliabel \\
\hline
\end{tabular}

Sumber: Hasil analisis, 2019

Berdasarkan tabel 3 tersebut, menunjukkan bahwa semua instrumen adalah reliabel, karena nilai alpha lebih besar dari 0,6.

\subsection{Analisis Uji Asumsi Klasik}

Dalam uji asumsi dianggap sebagai uji prasyarat yang merupakan bentuk uji pendahuluan atau syarat yang terlebih dahulu dipenuhi sebelum menggunakan untuk menguji dari hipotesis yang diajukan (Sugiyono \& Susanto, 2015, p. 318). Beberapa uji asumsi klasik yang perlu dipenuhi, antara lain sebagai berikut:

\subsubsection{Uji Normalitas}

Dalam penelitian ini, uji normalitas yang digunakan adalah uji Kormogorov-Smirnov. Uji KormogorovSmirnov untuk mengetahui nilai residual berdistribusi normal atau tidak. Jika nilai signifikasi $>0,05$, maka residual menyebar normal, dan apabila nilai signifikasi $<0,05$, maka tidak berdistribusi normal. Hasil uji
Kormogorov-Smirnov menggunakan program aplikasi SPSS, dapat dilihat pada Tabel 4.

Tabel 4 Hasil Uji Normalitas Kormogorov-Smirnov

\begin{tabular}{|c|c|}
\hline & Unstandardized Residual \\
\hline $\mathrm{N}$ & 58 \\
\hline $\begin{array}{c}\text { Test Statistic } \\
\text { (Kolmogorov-Smirnov) }\end{array}$ & 0,113 \\
\hline Asymp. Sig (2-tailed) & 0,063 \\
\hline
\end{tabular}

Sumber: Hasil analisis, 2019

Berdasarkan tabel tersebut, menunjukkan nilai signifikasi adalah 0,063 yang lebih besar dari 0,05, sehingga dapat disimpulkan bahwa berdistribusi normal.

\subsubsection{Uji Multikolinieritas}

Dalam penelitian ini uji multikolinieritas dilakukan dengan menggunakan Variance Inflation Factor (VIF). Apabila harga koefisien VIF hitung pada collinearity statistics $<10$, dan tolerance $>0,10$, maka tidak terdapat hubungan antar variabel independent (bebas), yang artinya tidak terjadi gejala multikolinieritas. Dan apabila harga koefisien VIF hitung pada collinearity statistics $>10$, dan tolerance $<0,10$, maka terdapat hubungan antar variabel independent (bebas), yang artinya terjadi gejala multikolinieritas (Sudarmanto, 2013, p. 239). Hasil uji multikolinieritas menggunakan program aplikasi SPSS, dapat dilihat pada Tabel 5.

Tabel 5 Hasil Uji Multikolinieritas

\begin{tabular}{|c|c|c|c|}
\hline Variabel Bebas & $\begin{array}{c}\text { Variance } \\
\text { Inflation } \\
\text { Factor } \\
\text { (VIF) }\end{array}$ & Tolerance & Keterangan \\
\hline $\begin{array}{c}\text { Perencanaan } \\
\text { (X1) }\end{array}$ & 1,955 & 0,511 & $\begin{array}{c}\text { Tidak Terjadi } \\
\text { Multikolinieritas }\end{array}$ \\
\hline $\begin{array}{c}\text { Penganggaran } \\
\text { (X2) }\end{array}$ & 1,955 & 0,511 & $\begin{array}{c}\text { Tidak Terjadi } \\
\text { Multikolinieritas }\end{array}$ \\
\hline
\end{tabular}

Sumber: Hasil analisis, 2019

\subsubsection{Uji Heteroskedastisitas}

Dalam penelitian ini dilakukan uji heteroskedastisitas menggunakan uji Glejser. Uji Glejser ini pada dasarnya dilakukan dengan meregresikan variabel-variabel bebas terhadap nilai absolut residualnya. Uji Glejser ini apabila nilai signifikasi > 0,05 , maka tidak terjadi heteroskedastisitas, dan apabila nilai signifikasi $<0,05$, maka terjadi heteroskedastisitas. Hasil uji heteroskedastisitas menggunakan program aplikasi SPSS, dapat dilihat pada Tabel 6.

Tabel 6 Hasil Uji Heteroskedastisitas

\begin{tabular}{|c|c|c|}
\hline Variabel Bebas & Signifikasi & Keterangan \\
\hline $\begin{array}{c}\text { Perencanaan } \\
\text { (X1) }\end{array}$ & 0,692 & $\begin{array}{c}\text { Tidak Terjadi } \\
\text { Heteroskedastisitas }\end{array}$ \\
\hline $\begin{array}{c}\text { Penganggaran } \\
\text { (X2) }\end{array}$ & 0,864 & $\begin{array}{c}\text { Tidak Terjadi } \\
\text { Heteroskedastisitas }\end{array}$ \\
\hline
\end{tabular}

Sumber: Hasil analisis, 2019 
Berdasarkan tabel tersebut, menunjukkan signifikasi untuk variabel perencanaan (X1) sebesar 0,692>0,05, maka tidak terjadi Heteroskedastisitas. Dan untuk nilai signifikasi untuk variabel penganggaran (X2) sebesar $0.864>0,05$, maka tidak terjadi Heteroskedastisitas.

\subsubsection{Uji Autokorelasi}

Dalam penelitian ini dilakukan uji autokorelasi menggunakan uji Durbin-Watson (DW Test). Data pengamatan apabila nilai statistk Durbin-Watson mendekati angka 2, maka tidak memiliki autokorelasi, hal ini merupakan ukuran yang digunakan untuk menilai autokorelasi (Sudarmanto, 2013, p. 264). Selanjutnya hasil uji autokorelasi menggunakan program aplikasi SPSS, pada Tabel 7.

Tabel 7 Hasil Uji Autokorelasi

\begin{tabular}{|c|c|c|c|c|c|}
\hline $\begin{array}{c}\text { Durbin- } \\
\text { Watson } \\
\text { (d) }\end{array}$ & $\mathrm{dL}$ & $\mathrm{dU}$ & $4-\mathrm{dL}$ & $4-\mathrm{dU}$ & \multicolumn{1}{|c|}{ Keterangan } \\
\hline 1,641 & 1,54 & 1,61 & 2,46 & 2,39 & $\begin{array}{l}=\mathrm{dU}<\mathrm{d}<4-\mathrm{dU} \\
=1,61<1,641<2,39 \\
\text { Tidak terdapat } \\
\text { autokoreksi }\end{array}$ \\
\hline
\end{tabular}

Sumber: Hasil analisis, 2019

\subsubsection{Uji Linieritas}

Dalam penelitian ini dilakukan uji liniearitas menggunakan uji test for linearity. Kaidah dalam menilai linieritas menurut Sudarmanto (2013, p. 207) terdiri dari dua faktor, yaitu sebagai berikut:

a) Koefisien $F_{\text {hitung }}$ pada Deviation from Linierity $<\mathrm{F}_{\text {tabel }}$ maka kecenderungan (trend) antara variabel dependent dan independent berbentuk garis lurus (linier); dan

b) Koefisien signifikansi pada Deviation from Linierity $>0,05$ maka dapat dinyatakan hubungan antara variabel dependent dan independent cenderung berbentuk garis lurus (linier).

Hasil uji liniearitas menggunakan program aplikasi SPSS, dapat dilihat pada Tabel 8 dibawah ini:

Tabel 8 Hasil Uji Liniearitas

\begin{tabular}{|c|l|c|c|c|}
\hline No. & \multicolumn{1}{|c|}{ Variabel } & Fhitung & $\mathrm{F}_{\text {tabel }}$ & $\begin{array}{c}\text { Koefisien } \\
\text { Signifikansi }\end{array}$ \\
\hline a. & $\begin{array}{l}\mathrm{Y} * \mathrm{X} 1 \\
\text { Kinerja * Perencanaan }\end{array}$ & 0,919 & 1,85 & 0,551 \\
\hline b. & $\begin{array}{l}\mathrm{Y} * \mathrm{X} 2 \\
\text { Kinerja * Penganggaran }\end{array}$ & 0,418 & 1,81 & 0,972 \\
\hline
\end{tabular}

Sumber: Hasil analisis, 2019

Berdasarkan tabel diatas, maka Fhitung < Ftabel dan koefisien signifikansi $>005$, sehingga antar variabel berbentuk garis lurus (linier).

\subsection{Hasil Uji Hipotesis}

Variabel-variabel yang digunakan dalam penelitian ini terdiri dari dua variabel bebas (independent), yaitu perencanaan dan penganggaran dan satu variabel terikat (dependent), yaitu kinerja perangkat daerah. Untuk menguji hipotesis, maka perlu dilakukan analisis data.

Untuk menguji hipotesis secara parsial maka digunakan uji t, yaitu untuk mengetahui pengaruh independent secara parsial terhadap variabel dependent. Dengan kriteria pengujian jika $t_{\text {hitung }}>t_{\text {tabel }}$ atau dengan nilai signifikansi $<0,05$, maka terdapat pengaruh variabel bebas (independent) simultan terhadap variabel terikat (dependent), dan jika $t_{\text {hitung }}<t_{\text {tabel }}$ atau dengan nilai signifikansi $>0,05$, maka tidak ada pengaruh.

Tabel 9 Hasil Uji t

\begin{tabular}{|c|c|c|}
\hline Model & $t$ & Sig \\
\hline Perencanaan (X1) & 2.136 & .037 \\
\hline Penganggaran (X2) & 5.863 & .000 \\
\hline
\end{tabular}

Sumber: Hasil analisis, 2019

Setelah dilakukan pengolahan data, dengan menggunakan program aplikasi SPSS, maka didapatkan hasil uji $\mathrm{t}$ yang dapat dilihat pada tabel 9, sehingga didapatkan hasil sebagai berikut:

a) Hasil uji t variabel perencanaan (X1) menunjukkan bahwa nilai $t_{\text {hitung }}$ sebesar 2,136 dengan nilai signifikansi sebesar 0,037 , hal ini menunjukkan $t_{\text {hitung }}(2,136)>t_{\text {tabel }}(2,004)$ dengan nilai signifikansi $(0,037)<0,05$, sehingga H0 ditolak, hal ini dapat diartikan bahwa secara parsial variabel perencanaan (X1) mempunyai pengaruh signifikan terhadap variabel kinerja perangkat daerah (Y); dan

b) Hasil uji t variabel penganggaran (X2) menunjukkan bahwa nilai thitung sebesar 5,863 dengan nilai signifikansi sebesar 0,000 , hal ini menunjukkan $t_{\text {hitung }}(5,863)>t_{\text {tabel }}(2,004)$ dengan nilai signifikansi $(0,000)<0,05$, sehingga $\mathrm{H} 0$ ditolak, hal ini dapat diartikan bahwa secara parsial variabel penganggaran (X2) mempunyai pengaruh signifikan terhadap variabel kinerja perangkat daerah (Y).

Berdasarkan hasil uji t terhadap kedua variabel bebas tersebut diatas, menunjukkan bahwa secara parsial kedua variabel bebas, yaitu variabel perencanaan (X1) dan penganggaran (X2) berpengaruh signifikan terhadap variabel terikat, yaitu variabel kinerja perangkat daerah. Sehingga hipotesis kedua yang menyatakan "Terdapat hubungan yang positif dan signifikan antara variabel perencanaan (X1) dan variabel penganggaran (X2) secara parsial terhadap kinerja perangkat daerah (Y)" dapat diterima kebenarannya.

Selajutnya dilakukan uji koefisien determinasi. Analisis determinasi digunakan untuk menunjukkan seberapa besar perencanaan dan penganggaran dapat meramalkan kinerja perangkat daerah pada Bappeda Kabupaten Kutai Timur. Hasil perhitungan menunjukkan bahwa persentase pengaruh variabel independent (perencanaan dan penganggaran) terhadap variabel dependent (kinerja perangkat), sebesar $66,7 \%$. 
Sedangkan sisanya sebesar $33,3 \%$ dipengaruhi oleh faktor lain diluar model penelitian ini.

\subsection{Pembahasan Hasil}

\subsubsection{Pengaruh Perencanaan terhadap Kinerja Perangkat Daerah}

Berdasarkan hasil uji $\mathrm{t}$ yang telah dilakukan, menunjukkan bahwa nilai thitung sebesar 2,136 dengan nilai signifikansi sebesar 0,037 , hal ini memiliki arti bahwa perencanaan berpengaruh signifikan dan positif terhadap kinerja Perangkat Daerah Bappeda Kabupaten Kutai Timur Provinsi Kalimantan Timur. Pengaruh positif menunjukkan perencanaan berkorelasi positif terhadap kinerja perangkat daerah, hal ini menandakan jika perumusan dan perencanaan strategi baik maka akan berdampak positif terhadap kinerja perangkat daerah. Pengaruh signifikan menunjukkan bahwa kualitas perencanaan mempunyai peranan sangat penting dalam meningkatkan kinerja perangkat daerah.

Hasil penelitian ini sejalan dengan teori yang dikemukakan oleh Suhadak \& Nugroho (2007, p. 21), yaitu dalam anggaran berbasis kinerja yang indikator kinerja serta target/ sasaran dalam melaksanakan program/ kegiatan harus terukur jelas, yaitu dengan cara membentuk sistem penganggaran yang memadukan antara perencanaan kinerja dan penganggaran.

Penelitian ini juga sejalan dengan konsep yang dikemukakan oleh Mahsun (2014, p. 37), membagi sistem pengukuran kinerja menjadi 5 lima tahapan (Perumusan Strategi, Perencanaan Strategi, Penganggaran, Pelaksanaan Anggaran Dan Evaluasi Kinerja). Sementara itu, konsep perencanaan kinerja dibagi kedalam dua tahapan, yaitu perumusan strategi dan perencanaan strategi, yang kemudian dilanjutkan kedalam proses penganggaran.

Selain itu juga sejalan dengan yang dikemukakan oleh Mahmudi (2015, p. 61), untuk mewujudkan tujuan organisasi, proses pengendalian manajemen dapat dilakukan dalam delapan tahapan, yaitu sebagai berikut:
a) Perumusan Strategi;
b) Perencanaan Strategi;
c) Pembuatan Program,
d) Penganggaran,
e) Implementasi,
f) Pelaporan Kinerja,
g) Evaluasi Kinerja; dan
h) Umpan Balik.

Untuk memberikan jaminan tercapainya misi, visi, dan tujuan organisasi, maka organisasi harus menciptakan koherensi antar elemen dalam sistem pengendalian manajemennya. Perumusan strategi, perencanaan strategi, pemprograman, penganggaran, implementasi, pelaporan dan evaluasi kinerja harus koheren, terpadu, dan berkesinambungan (Mahmudi, 2015, p. 77).
Hasil penelitian ini juga sejalan dengan hasil penelitian yang dilakukan oleh Ahmari \& Amar (2014), tentang Pengaruh Perencanaan, Pelaksanaan Dan Pengendalian Anggaran Terhadap Kinerja Satuan Kerja Perangkat Daerah (SKPD) Kabupaten Kepulauan Mentawai, menunjukkan bahwa perencanaan anggaran berpengaruh posistif dan signifikan terhadap pelaksanaan anggaran, perencanaan dan pelaksanaan anggaran berpengaruh posistif dan signifikan terhadap pengendalian anggaran dan perencanaan, pelaksanaan dan pengendalian anggaran berpengaruh signifikan terhadap Kinerja SKPD.

Selain itu hasil penelitian ini sejalan dengan hasil penelitian yang dilakukan oleh Motondang, Basri, dan Arfan (2015) tentang Pengaruh Sinkronisasi Perencanaan dan Penganggaran, Partisipasi Anggaran dan Kejelasan Sasaran Anggaran terhadap Kinerja SKPD pada Pemerintah Kabupaten Aceh Utara; menunjukkan bahwa sinkronisasi Perencanaan dan Penganggaran, Partisipasi Anggaran dan Kejelasan Sasaran Anggaran berpengaruh terhadap Kinerja SKPD.

Selain itu juga hasil penelitian ini sejalan dengan hasil penelitian yang dilakukan oleh Wijaya G (2018) tentang Analisis Pengaruh Konsistensi Perencanaan dan Penganggaran Terhadap Efektivitas dan Efisiensi Program Pembangunan Daerah Studi pada Bappeda Provinsi Sulawesi Barat; menunjukkan bahwa konsistensi perencanaan memiliki pengaruh yang positif terhadap efektivitas dan efisiensi program pembangunan daerah, begitu juga dengan konsistensi penganggaran yang memiliki pengaruh positif, namun berbeda halnya dengan sinkronisasi perencanaan dan penganggaran yang tidak berpengaruh terhadap efektivitas dan efisiensi program pembangunan daerah.

Hasil penelitian ini juga mendukung regulasi dari pasal 180 Peraturan Menteri Dalam Negeri Nomor 86 Tahun 2017, bahwa dalam pengendalian dan evaluasi perencanaan pembangunan daerah bertujuan untuk mewujudkan konsistensi antara RKPD dengan RPJMD. Selain itu menurut pasal 124 Rencana Strategis (Renstra) Perangkat Daerah menjadi pedoman kepala Perangkat Daerah dalammenyusun Rencana Kerja (Renja) Perangkat Daerah dan digunakan dalam penyusunan rancangan RKPD.

Berdasarkan analisis yang dilakukan peneliti, perencanaan pada Bappeda Kabupaten Kutai Timur Provinsi Kalimantan Timur secara keseluruhan sudah sangat baik, hal ini tercermin dari hasi analisis jawaban responden atas item-item peryataan tentang perencanaan, dimana nilai rata-rata pada setiap item masuk dalam kategori sangat setuju.

Selain itu untuk mengukur kinerja perangkat daerah pada Bappeda khususnya dalam perencanaan dapat dilihat didalam indikator kinerja. Perencanaan pada Bappeda Kabupaten Kutai Timur secara keseluruhan 
sudah sangat baik, hal ini didukung dengan terdapatnya indikator kinerja didalam Rencana Strategis Bappeda Kabupaten Kutai Timur, yang kemudian dilakukan evaluasi setiap tahunnya di dalam dokumen Laporan Kinerja Instansi Pemerintah (LKjIP) Bappeda Kabupaten Kutai Timur. Indikator kinerja tentang perencanaan yang menunjukkan tentang penjabaran konsistensi program dalam dokumen lima tahunan Rencana Pembangunan Jangka Menengah Daerah (RPJMD) Kabupaten Kutai Timur kedalam dokumen tahunan Rencana Kerja Pemerintah Daerah (RKPD) Kabupaten Kutai Timur. Kinerja Perangkat Daerah tentang perencanaan salah satunya dapat dilihat dari indikator kinerja yang setiap tahun dilakukan penilaian dan evaluasi, yaitu pada indikator kierja "Penjabaran Konsistensi Program RPJMD kedalam RKPD” yang dari Tahun 2016-2017 mempunyai interpretasi "Memuaskan", yaitu nilai angka > 80-90 (berdasarkan Peraturan Menteri PAN-RB Nomor 12 Tahun 2015).

\subsubsection{Pengaruh Penganggaran Terhadap Kinerja Perangkat Daerah}

Berdasarkan hasil uji $\mathrm{t}$ yang telah dilakukan, menunjukkan bahwa thitung sebesar 5,863 dengan nilai signifikansi sebesar 0,000, hal ini memiliki arti bahwa penganggaran berpengaruh signifikan dan positif terhadap kinerja Perangkat Daerah Bappeda Kabupaten Kutai Timur Provinsi Kalimantan Timur. Pengaruh positif menunjukkan perencanaan berkorelasi positif terhadap kinerja perangkat daerah, hal ini menandakan jika dalam proses penganggaran berpedoman pada Standar Pelayanan Minimal, Indikator Kinerja, Analisis Standar Biaya, dan Standar Satuan Harga maka akan berdampak positif terhadap kinerja perangkat daerah. Pengaruh signifikan menunjukkan bahwa kualitas penganggaran mempunyai peranan sangat penting dalam meningkatkan kinerja perangkat daerah.

Hasil penelitian ini sejalan dengan teori yang dikemukakan oleh Suhadak \& Nugroho (2007, p. 21), penganggaaran kinerja yang menilai sistem anggaran kinerja menjadi empat tolak ukur, yaitu: SPM, Indikator Kinerja, ASB, dan Standart Satuan Harga. Dan juga dalam anggaran berbasis kinerja yang indikator kinerja serta target/ sasaran dalam melaksanakan program/ kegiatan harus terukur jelas, yaitu dengan cara membentuk sistem penganggaran yang memadukan antara perencanaan kinerja dan penganggaran.

Penelitian ini juga sejalan dengan yang dikemukakan oleh Mardiasmo (2002a, p. 84), bahwa anggaran kinerja adalah sistem anggaran yang mengutamakan pencapaian output dari input yang ditetapkan. Anggaran kinerja didasarkan pada tujuan dan sasaran kinerja.

Hasil penelitian ini juga sejalan dengan hasil penelitian yang dilakukan oleh oleh Motondang, Basri \&
Arfan (2015) tentang Pengaruh Sinkronisasi Perencanaan dan Penganggaran, Partisipasi Anggaran dan Kejelasan Sasaran Anggaran terhadap Kinerja SKPD pada Pemerintah Kabupaten Aceh Utara; menunjukkan bahwa sinkronisasi Perencanaan dan Penganggaran, Partisipasi Anggaran dan Kejelasan Sasaran Anggaran Berpengaruh terhadap Kinerja SKPD.

Selain itu, hasil penelitian ini sejalan dengan hasil penelitian yang dilakukan oleh Dewi Kurniasari dkk., (2017) tentang Pengaruh Anggaran Berbasis Kinerja Terhadap Efektivitas Pengendalian Anggaran di Dinas Pendapatan dan Pengelolaan Keuangan dan Aset Daerah Kabupaten Bandung Barat; menunjukkan bahwa dimensi efektif, efisien, dan ekonomis dalam anggaran berbasis kinerja berpengaruh terhadap efektivitas pengendalian anggaran.

Selain itu juga hasil penelitian ini sejalan dengan hasil penelitian yang dilakukan oleh Wijaya G (2018) tentang Analisis Pengaruh Konsistensi Perencanaan dan Penganggaran Terhadap Efektivitas dan Efisiensi Program Pembangunan daerah Studi pada Bappeda Provinsi Sulawesi Barat; menunjukkan bahwa konsistensi perencanaan memiliki pengaruh yang positif terhadap efektivitas dan efisiensi program pembangunan daerah, begitu juga dengan konsistensi penganggaran yang memiliki pengaruh positif, namun berbeda halnya dengan sinkronisasi perencanaan dan penganggaran yang tidak berpengaruh terhadap efektivitas dan efisiensi program pembangunan daerah.

Hasil penelitian ini juga mendukung regulasi dari pasal 93-95 Peraturan Pemerintah Nomor 12 Tahun 2019 tentang Pengelolaan Keuangan Daerah; bahwa dalam menyusun Rencana Kerja dan Anggaran (RKA) Satuan Kerja Perangkat Daerah (SKPD) berdasarakan KUAPPAS dengan pendekatan penganggaran berdasarkan kinerja dengan memadukan seluruh proses perencanaan dan penaganggaran di lingkungan SKPD.

Analisis tentang pentingnya anggaran kinerja yang memadukan antara perencanaan dengan penganggaran belum pernah dilakukan di Kabupaten Kutai Timur, khususnya di Bappeda, karena penilain kinerja perangkat daerah hanya dilihat dari sisi penilaian realisasi capaian target indikator kinerja menurut Peraturan Presiden Nomor 29 Tahun 2014 tentang Sistem Akuntabilitas Kinerja Instansi Pemerintah. Sedangkan penilaian kinerja perangkat daerah memiliki banyak parameter pengukuran, mulai dari proses perumusan yang sesuai dengan visi misi, perencanaan strategi yang berupa program dan kegiatan yang mendukung tujuan, program/ kegiatan untuk pemenuhan Standart Pelayanan Minimal (SPM), kewajaran dalam penentuan standar dari kegiatan dengan menggunakan Analisis Standar Biaya (ASB) dan juga dalam penetapan harga satuan. Selain itu, indikator kinerja di Bappeda Kabupaten Kutai Timur juga masih sebatas menyesuaikan dengan Peraturan Menteri Dalam 
Negeri Nomor 86 Tahun 2017, yang hanya melihat dari sisi tersedianya dokumen, belum menilai sampai pada tingkat konsistensi program/ kegiatan dari dokumen perencanaan (Rencana Strategis dan Rencana Kerja) kedalam dokumen penganggaran (Rencana Kerja Anggaran SKPD).

\section{Kesimpulan}

Berdasarkan hasil uji hipotesis dan pembahasan dalam penelitian ini, maka dapat diambil kesimpulan bahwa perencanaan mempunyai pengaruh yang positif dan siginfikan terhadap kinerja perangkat daerah pada Bappeda Kabupaten Kutai Timur Provinsi Kalimantan Timur dan penganggaran juga mempunyai pengaruh yang positif dan siginifikan terhadap kinerja perangkat daerah pada Bappeda Kabupaten Kutai Timur Provinsi Kalimantan Timur.

Pengaruh perencanaan dan penganggaran terhadap kinerja mempunyai pengaruh sebesar $66,7 \%$. Sedangkan sisanya sebesar 33,3\% dipengaruhi oleh faktor lain diluar model penelitian ini.

\section{Daftar Pustaka}

Ahmari, Amir., \& Amar, Syamsul. (2014). Pengaruh Perencanaan, Pelaksanaan Dan Pengendalian Anggaran Terhadap Kinerja Satuan Kerja Perangkat Daerah (SKPD) Kabupaten Kepulauan Mentawai. Jurnal Riset dan Manajemen Bisnis, Vol. 2, pp. 1-12.

Bastian, Indra. (2009). Sistem Perencanaan dan Penganggaran Pemerintahan Daerah di Indonesia. Jakarta: Salemba Empat.

Bastian, Indra. (2010). Akuntansi Sektor Publik: Suatu Pengantar. Jakarta: Erlangga.

Caiden, Naomi., \& Wildavsky, Aaron. (1974). Planning and Budgeting in Poor Countries. USA: The Thwentieth Century Fund, Inc.

Effendi, Sofian., \& Tukiran. (2017). Metode Penelitian Survei. Jakarta: LP3ES.

Halim, Abdul., \& Kusufi, Muhammad Syam. (2014). Teori, Konsep dan Aplikasi Akuntansi Sektor Publik: Dari Anggaran Hingga Laporan Keuangan, Dari Pemerintah Hingga Tempat Ibadah. Jakarta: Salemba Empat.

Hakim, Abdul. (2016). Metode Kuantitatif untuk IlmuIlmu Sosial. Malang: Cita Intrans Selaras.

Hanafi, Imam., \& Mugroho, Tri Laksono. (2009). Kebijakan Keuangan Daerah Reformasi dan Model Pengelolaan Keuangan Daerah di Indonesia. Malang: Universitas Brawijaya Press.

Hardjanto, Imam. (2011). Teori Pembangunan. Malang: Universitas Brawijaya Press.

Khusaini, Mohammad. (2006). Ekonomi Publik: Desentralisasi Fiskal dan Pembangunan Daerah.
Malang: Badan Penerbit Fakultas Ekonomi Universitas Brawijaya.

Kurniasari, Dewi., Kurniasari, Dedeh., \& Marta, M. Sandy. (2017). Pengaruh Anggaran Berbasis Kinerja Terhadap Efektivitas Pengendalian Anggaran di Dinas Pendapatan dan Pengelolaan Keuangan dan Aset Daerah Kabupaten Bandung Barat. Publisia: Jurnal Ilmu Administrasi Publik, 3(2), 140-150.

Mahmudi. (2015). Manajemen Kinerja Sektor Publik. Yogyakarta: Sekolah Tinggi Ilmu Manajemen YKPN.

Mahsun, Muhamad. (2014). Pengukuran Kinerja Sektor Publik. Yogyakarta: BPFE.

Mahsun, Moh., Sulistiyowati, Firma., \& Purwanugraha, Heribertus Andre. (2016). Akuntansi Sektor Publik. Yogyakarta: BPFE.

Mardiasmo. (2002a). Akuntansi Sektor Publik. Yogyakarta: Andi.

Mardiasmo. (2002b). Otonomi dan Manajemen Keuangan Daerah. Yogyakarta: Andi.

Mindarti, Lely Indah. (2016). Aneka Pendekatan dan Teori Dasar Administrasi Publik. Malang: Universitas Brawijaya Press.

Motondang, Nova Idea., Basri, Hasan., \& Arfan, Muhammad. (2015). Pengaruh Sinkronisasi Perencanaan dan Penganggaran, Partisipasi Anggaran dan Kejelasan Sasaran Anggaran Terhadap Kinerja SKPD Pada Pemerintah Kabupaten Aceh Utara. Jurnal Administrasi Akuntansi, 4(4), 36-45.

OECD. (2018). Best Practices for Performance Budgeting. Diakses 20 Mei 2019, dari https://one.oecd.org/document/GOV/PGC/SBO(2 018)7/en/pdf

Sjafrizal. (2017). Perencanaan Pembangunan Daerah Dalam Era Otonomi. Jakarta: Rajawali Pers.

Sudarmanto, R. Gunawan. (2013). Statistik Terapan Berbasis Komputer dengan Program IBM SPSS Statistik 19. Jakarta: Penerbit Mitra Wacana Media.

Sugiyono., \& Susanto, Agus. (2015). Cara Mudah Belajar SPSS dan Lisrel . Bandung: Alfabeta CV.

Sugiyono. (2017). Metode Penelitian Kuantitatif, Kualitatif, dan $R \& D$. Bandung: Alfabeta CV.

Suhadak., \& Nugroho Trilaksono. (2007). Paradigma Baru Pengelolaan Keuangan Daerah Dalam Penyusunan APBD di Era Otonomi. Malang: Bayumedia Publishing.

Sun'an, Muammil., \& Senuk, Abdurrahman. (2015). Ekonomi Pembangunan Daerah. Jakarta: Mitra Wacana Media.

Wijaya G, Angga Tirta. (2018). Analisis Pengaruh Konsistensi Perencanaan dan Penganggaran Terhadap Efektivitas dan Efisiensi Program 
Pembangunan Daerah (Studi pada Bappeda Provinsi Sulawesi Barat). (Tesis Tidak Dipublikasikan). UGM, Yogyakarta. 